\title{
KOLABORASI MASYARAKAT SIPIL, POLITIK, DAN EKONOMI DALAM PEMANFAATAN MODAL SOSIAL \\ (Studi Kasus Daerah Perlindungan Laut di Desa Bondalem, Kabupaten Buleleng)
}

\author{
Ketut Sedana Arta \\ Jurusan Pendidikan Sejarah, Fakultas IImu Sosial, \\ Universitas Pendidikan Ganesha, \\ Singaraja, Indonesia
}

\begin{abstract}
Abstrak
Tujuan penelitian ini adalah (1) Untuk mengetahui alasan maknawi/motif yang memberikan dorongan bagi Desa Bondalem membentuk Daerah Perlindungan Laut; (2) Untuk mengetahui unsur-unsur pokok modal sosial apa saja yang dikenal pada komunitas desa Bondalem yang bisa dikolaborasikan dalam kaitannya dengan modal-modal lainya; (3) Untuk mengetahui implikasi penyertaan modal sosial terhadap kehidupan komunitas desa Bondalem sebagai Daerah Perlindungan Laut.

Penelitian ini secara metodologis menggunakan pendekatan kualitatif. Hasil Penelitian ini menunjukkan Alasan maknawi Bondalem yang terkait dengan superstruktur ideologi, struktur sosial, dan infrastruktur material yang memberikan dorongan bagi desa membentuk Daerah Perlindungan laut adalah 1) adanya ideologi Tri Hita Karana yang menginspirasi setiap langkah dan tindakan untuk menyelamatkan terumbu karang. Struktur sosial yang berperan terhadap pembentukan DPL di Bondalem adalah pihak pemerintah dalam hal ini diwakili oleh Dinas Kelautan dan Perikanan, LSM (Reef Check Indonesia), pihak pelaku pariwisata (pemilik hotel), unsur masyarakat Bondalem sendiri seperti desa dinas, desa pakraman, dan Pecalang Segara. Unsur-unsur modal sosial yang dikenal di Desa Bondalem adalah 1)Ideologi Tri Hita Karana, yang sudah diterapkan bukan lagi dalam tataran teks serta dapat dijadikan resep sosial dalam pembentukan DPL-BM di Desa Bondalem, 2) Trust yang tampak adalah berwujud keinginan dan atau tindakan untuk mengambil resiko dalam hubungan-hubungan sosial, 3) Nilai-nilai dan norma dituangkan dalam aturan awig-awig yang mengatur aspek parhyangan, pawongan dan palemahan. 4) Resiprositas, dalam konteks ini menyangkut resiprositas desa pakraman, desa dinas, pecalang segara serta resiprositas antarlembaga seperti pemerintah pemilik hotel. 5) Tindakan proaktif, berupa keinginan yang kuat dari anggota kelompok tidak saja untuk berpartisipasi, namun juga mencari jalan yang lebih baik secara proaktif. 6) Kepercayaan terhadap kekuatan adikodrati yakni dewa-dewa dan roh leluhur yang ditaati karena dapat melakukan pengawasan dan mengenakan sanksi kepada siapapun tanpa terikat oleh waktu dan ruang. Implikasi penyertaan modal sosial terhadap kehidupan komunitas Desa Bondalem sebagai Daerah perlindungan laut adalah 1) lestarinya terumbu karang, 2)meningkatnya hasil tangkapan ikan, 3)Meningkatnya kunjungan wisatawan untuk melakukan diving dan snokling yang berimbas kenaikan pada tingkat hunian hotel.
\end{abstract}

Kata Kunci: Kolaborasi, Modal Sosial, Daerah Perlindungan Laut. 


\begin{abstract}
Target of this research is (1) To know the reason of maknawi/motif giving motivation to Countryside of Bondalem form Protectorate Sea; (2) To know fundamental elements of social capital any kind of which is recognized at countryside community of Bondalem which can dikolaborasikan in its bearing with its capitals of him; (3) To know implication and also social capital to life of countryside community of Bondalem as Protectorate Sea.

This research methodologically use approach qualitative. Result of this Research show the Reason of Bondalem maknawi which related to ideology superstructure, social structure, and infrastructure of material giving motivation to countryside form Protectorate go out to sea is 1) existence of ideology Three Hita Karana which is inspiration each;every action and step to save rock terumbu. Social structure which sharing to forming of DPL in Bondalem is governmental side in this matter represented by On duty Oceaninc and Fishery, LSM (Reef Check Indonesia), side perpetrator of tourism (owner of hotel), society element of Bondalem alone like countryside on duty, countryside of pakraman, and Pecalang Segara. social Capital elements which recognized in Countryside of Bondalem is 1)Ideologi Three Hita Karana, which have been applied [by] not again in text tataran and also can be made by social recipe in forming of DPL-BM in Countryside of Bondalem 2) visible Trust is extant of desire and or action to risk in social relation 3) Values and norm poured in order of awig-awig arranging aspect of parhyangan, and pawongan of palemahan 4) Resiprositas, in this context concerning countryside resiprositas of pakraman, countryside on duty, pecalang of segara and also antarlembaga resiprositas like government of owner of hotel 5) action of Proaktif, in the form of strong desire of group member not even to participate, but also look for better road;street by proaktif 6) Trust to strength of adikodrati namely ancestor soul and deitys adhered by because can do observation and sanction to whoever without engagement by room and time. Implication and also social capital to life of Countryside community of Bondalem as Protectorate go out to sea is 1) making everlasting of rock terumbu, its of fish haul him, its of tourist visit him to do and diving of snokling which induce increase at hotel dwelling storey;level
\end{abstract}

Keywords: Kolaborasi, Social Capital, Protectorate Sea.

\section{PENDAHULUAN}

Masyarakat Bali memiliki ideologi Tri Hita Karana. Ideologi ini menggariskan bahwa manusia harus hidup harmonis antarsesamanya (Pawongan), antara manusia dan alam (Palemahan), dan antara manusia dan Tuhan, dewa-dewa maupun roh leluhur (Atmadja, 1988; Titib, 2003, Wiana, 1993). Ideologi Tri Hita Karena berkaitan erat dengan agama Hindu sehingga legitimasinya amat kuat (Prime, 2006). Begitu pula agama Hindu sangat menekankan pada ahimsa atau nirkekerasan yang di dalamnya mencakup larangan melakukan kekerasan terhadap alam (Shastri dan Shastri, 2005). Namun kenyataannnya kerusakan terumbu karang yang terjadi di daerah Kecamatan Tejakula di bawah tahun 2000-an cukup parah, hal ini senada dengan laporan Reef at Risk (2002) menempatkan Indonesia sebagai salah satu negara dengan status terumbu karang yang paling terancam. Selama 50 tahun terakhir, proporsi penurunan kondisi terumbu karang Indonesia telah meningkat dari $10 \%$ menjadi $50 \%$. Lebih lanjut, hasil survey P2O LIPI (2006) menyebutkan bahwa hanya 5, 23\% terumbu karang di Indonesia yang berada di dalam kondisi yang sangat baik. Di balik fenomena kerusakan terumbu karang di 
Bali, ternyata Bondalem berhasil menjaga kelestarian laut, terbukti dari berhasilnya desa tersebut mengembangkan terumbu karang dan ikan hias

Karena itu paradigma pariwisata tidak lagi hanya dilihat dari segi ekonomi, tetapi memberikan pula ruang bagi penyertaaan dan penumbuhkembangan modal sosial. Hal ini sejalan pula dengan pandangan Pitana (2008: 212-213) tentang paradigma baru dalam pengembangan pariwisata, yakni paradigma berkualitas, berkelanjutan dan berkerakyatan. Berkenaan dengan itu pengelolaan Bali semestinya, dikembalikan kepada konsep pengelolaan Bali secara total, utuh dan menyeluruh. Dalam konteks inilah modal sosial menjadi penting. Bahkan, bisa dikatakan paradigma pariwisata berkualitas, berkelanjutan dan berkerakyatan pada dasarnya adalah berbasis modal sosial.

\section{HASIL PENELITIAN}

1. Alasan maknawi/motif yang terkait dengan superstruktur ideologi, struktur sosial, dan infrastruktur material yang memberikan dorongan bagi Desa Bondalem membentuk Daerah Perlindungan Laut.

$\begin{array}{ccc} & \text { Bapak Sadu Adnyana sebagai } \\ \text { pelopor pembentukkan } & \text { Daerah }\end{array}$

Perlindungan Laut mengatakan bahwa kesadaran masyarakat dan semua pihak yang terkait tentang arti penting terumbu karang untuk menjaga ekosistem laut membuktikan tentang pelaksanaan dari ideologi Tri Hita Karana. Diakuinya bahwa pada awal pembentukkan Daerah Perlindungan Laut banyak hambatan yang dihadapi, salah satunya adalah pesimisme dari tokoh-tokoh masyarakat yang tidak sepaham dengan beliau, para nelayan, pihak pelaku ekonomi (pihak hotel) yang mengganggap ide tersebut tidak akan bisa dilaksanakan. Namun dengan penuh kesabaran dan berbagai pendekatan seperti mengadakan pertemuan dalam rangka sosialisasi pentingnya terumbu karang bagi kelestarian laut dan untuk menjamin kesejahteraan penduduk dalam jangka panjang.

Menurut Sekdes Desa Bondalem Gde Arsa, mengatakan bahwa pihak Desa Dinas dan Pakraman mempunyai andil besar dalam pembentukkan Daerah Perlindungan laut. Desa Dinas bisa memberikan bantuan dengan pembentukan Perdes Bondalem No. 5 Tahun 2006 tentang Perlindungan Pesisir dan Laut. Perdes ini dilatarbelakangi semakin terbatasnya potensi sumber daya pesisir dan laut desa, untuk menjamin terselenggarakan kehidupan dan pembangunan yang berkelanjutan serta terpeliharanya fungsi lingkungan hidup, akibat dari tindakan, ancaman pemanfaatan, dan perusakan lingkungan pesisir dan laut dari masyarakat desa atau luar desa, maka wilayah pesisir dan laut perlu dilindungi. Perdes juga dibentuk dalam rangka menjamin pelestarian lingkungan hidup (darat, laut, udara), maka setiap orang berkewajiban untuk menjaga, mengawasi, dan memelihara lingkungan hidup terutama daerah pesisir dan laut yang dijamin oleh hukum dan perundang-undangan.

Berdasarkan wawancara dengan ketua kelompok Bahari Prawara, peran organisasi Yayasan Reef Check Indonesia mempunyai peran pembentukkan Daerah Perlindungan Laut dengan mengadakan beberapa kegiatan antara lain dengan Buleleng, 24 November 2006. Atas inisiatif masyarakat setempat, pada tanggal 13-14 November 2006, Tim Scientist Reef Check Indonesia melakukan program pelatihan 
penilaian sumberdaya partisipatif di Desa Bondalem kecamatan Tejakula, Buleleng. Seperti umumnya desa-desa di pesisir Bali, mata pencaharian utama masyarakat Bondalem adalah perikanan, rumput laut, dan pariwisata. Pelatihan diikuti sekitar 20 peserta, terdiri dari Kepala Desa, nelayan, karyawan hotel, dan beberapa orang asing yang menetap maupun sedang berkunjung di sana.

Untuk melengkapi sarana pemeliharaan dan pengawasan terumbu karang di Bondalem ini pemerintah melalui Dinas Perikanan Kelautan (DPK) Buleleng menyerahkan bantuan satu set peralatan selam. Bantuan diserahkan Rabu, tanggal 2 September 2009 oleh Kepala DPK Kabupaten Buleleng Ir. Nyoman Sutrisna kepada Perbekel Desa Bondalem pada waktu itu masih dijabat Ngurah Sadu Adnyana di kantor perbekel setempat. Bentuk bantuan lainnya adalah Kegiatankegiatan yang dilakukan diantaranya Beach and Reef Clean Up, Pengenalan terhadap guru-guru dan siswa sekolah dasar tentang pentingnya menjaga kelestarian sumberdaya pesisir serta dilakukan pula upaya rehabilitasi, yaitu proses membantu pemulihan kondisi ekosistem terumbu karang melalui pemasangan terumbu buatan jenis Hexadome dan "Roti Buaya" serta latihan teknik menyelam.

2. Unsur-unsur pokok modal sosial yang dikenal pada komunitas desa Bondalem yang bisa dikolaborasikan dalam kaitannya dengan modal-modal lainya (produce ekonomic capital, human capital, dan natural capital) guna mewujudkan pengembangan Daerah Perlindungan laut yang berkelanjutan termasuk di dalamnya

\section{hubungan mereka dengan lembaga-}

lembaga lain di luar desa mereka.

Adapun

komponen-komponen

modal sosial yang masih hidup di desa Bondalem adalah sebagai berikut:

1. Ideologi Tri Hita Karana

Modal sosial yang paling penting pada desa-desa yang tercakup dalam Kawasan wisata bahari termasuk Desa Bondalem atau bahkan Bali pada umumnya adalah ideologi Tri Hita Karana. Sesuai dengan labelnya, yakni Tri Hita Karana, maka Tri berarti tiga, Hita berarti kesejahteraan atau kebahagian, dan Karana berarti penyebab. Jadi, Tri Hita Karana berarti tiga penyebab kesejahteraan.

Berdasarkan wawancara dengan Kelian Desa Pakraman Bondalem, kata Tri Hita Karana berasal dari bahasa Sanskerta dimana kata Tri artinya tiga, Hita artinya sejahtra atau bahagia sedangkan Karana artinya sebab atau penyebab. Jadi Tri Hita Karana artinya tiga hubungan yang sangat harmonis yang mengakibatkan umat manusia mencapai kebahagiaan/kesejahtraan. Untuk itu ketiga hal tersebut harus dijaga dan dilestarikan agar kita bias mencapai hubungan yang harmonis. Sebagaimana dimuat dalam ajaran Agama Hindu bahwa kebahagiaan dan kesejahteraan adalah tujuan yang ingin dicapai dalam hidup manusia, baik kebahagiaan pisik atau lahiriah yang disebut "Jagadhita" maupun kebahagiaan rohaniah yang disebut "Moksa", kebahagiaan abadi.

\section{Rasa percaya mempercayai (trust)}

Pengamatan kancah yang disertai dengan wawancara mendalam yang dilakukan terhadap beberapa orang informan dapat diketahui, bahwa modal sosial yang tidak kalah pentingnya yang 
mereka miliki, yakni trust atau rasa percaya mempercayai. Trust yang tampak adalah berwujud keinginan dan atau tindakan untuk mengambil risiko dalam hubunganhubungan sosial, dengan suatu keyakinan, bahwa orang lain akan melakukan hal yang sama atau paling tidak mereka bertindak tidak merugikan dirinya sendiri maupun kelompoknya. Dengan mengacu kepada Fukuyama (2002, 2004, 2005) trust yang berwujud sikap saling mempercayai antarwarga masyarakat, amat penting, baik dalam rangka mewujudkan persatuan maupun memperkuat pengembangan modal sosial. Dengan mengacu kepada Qianhong Fu (dalam Hasbullah, 2006) trust berada pada tingkatan, yakni pada tingkatan idividu, tingkatan relasi sosial, dan sistem sosial. Pada tingkatan individu trust merupakan aspek personal dan sekaligus sebagai karakteristik individu. Pada tindakan hubungan sosial, trust merupakan atribut kolektif untuk mencapai tujuan kelompok. Sedangkan pada tingkatan sistem sosial merupakan nilai publik yang perkembangannya difasilitasi oleh sistem sosial yang ada termasuk dalam pembentukan DPL Bondalem.

\section{Nilai dan norma sosial}

Dengan berpegang pada ideologi Tri Hita Karana yang berlaku pada masyarakat Bali, maka dapat disimpulkan, bahwa nilai yang dijunjung tinggi pada masyarakat Bali adalah nilai-nilai harmoni, yakni harmoni dalam konteks hubungan antara manusia dan Tuhan, harmoni antara manusia dan manusia, dan harmoni antara manusia dan lingkungan. Penekanan pada harmoni menimbulkan implikasi, bahwa hal yang berlawanan dengannya, yakni konflik dianggap sebagai sesuatu yang tidak diidealkan pada masyarakat Bali.
Nilai-nilai Tri Hita Karana terlihat jelas dalam awig-awig Desa Pakraman Bondalem, yang secara tegas mengatur dan dijadikan pedoman dalam berinteraksi menyangkut hubungan manusia dengan Tuhan (Parhyangan), hubungan manusia dengan manusia (Pawongan), serta manusia dengan alam (Palemahan). Mengacu pada awig-awig Desa Pakraman Bondalem terdapat aturan sebagau berikut: "sahanan krama utawi warga desa tan kadadosang ngenahang luhu ring genah sane tan patut, minakadi ring tukad, got, pangkung, rawuhing segara, bilih-bilih pamargin toyane sampet, sejawaning ring genah sane sampun kacumawisang"(semua penduduk desa, dilarang membuang sampah sembarangan, seperti di got, pangkung, pantai yang menyebabkan terganggunya aliran air, dan membuangnya pada tempat yang telah ditentukan).

\section{Resiprositas}

Dalam konteks ini asas resiprositas juga tidak saja dalam tingkatan Desa Pakraman dan Desa Dinas, seka, dadia, pecalang segara, namun juga menyangkut resiprositas antar lembaga seperti unsur pemerintah (Dinas Kelautan dan Perikanan), pelaku ekonomi (pemilik dan pengelola hotel). Pemerintah berkepentingan untuk mendorong masyarakat ikut berpartisipasi dalam pelestarian terumbu karang karena menyadari keberhasilan program pemerintah akan terjadi apabila melibatkan masyarakat lokal dalam pelaksanaannya (berbasis masyarakat), pihak masyarakat desa Bondalem memerlukan berbagai bimbingan, penyuluhan dan pelatihan yang diberikan oleh pemerintah maupun LSM guna kelestarian terumbu karang untuk menjamin lahan penangkapan ikan tidak berkurang.

Jurnal IImu Sosial dan Humaniora | 121 


\section{Tindakan proaktif}

Modal sosial lain yang tidak kalah pentingnya adalah tindakan proaktif. Hal ini sejalan dengan apa yang dikemukakan Hasbullah (2006: 16) yang menyatakan, bahwa salah satu modal sosial adalah keinginan yang kuat dari anggota kelompok untuk tidak saja berpartisipasi, tetapi juga mencari jalan yang lebih baik secara proaktif. Tindakan proaktif ini dapat dilihat dari upaya-upaya yang dilakukan oleh Bapak Sadhu Adnyana yang berusaha menyadarkan masyarakat tentang pentingnya Desa Bondalem dalam membentuk daerah Perlindungan Laut. Tindakan proaktif menunjukkan bahwa DPL di Desa Bondalem adalah pengelolaan berbasis masyarakat, maksudnya adalah comanagement (pengelolaan bersama), yakni pengelolaan yang dilakukan oleh masyarakat bersama-sama dengan pemerintah setempat.

\section{Keyakinan terhadap kekuatan adikodrati}

Pendek kata, ada aspek tambahan modal sosial yang tidak kalah pentingnya pada desa-desa di Bondalem, yakni tidak hanya trust dalam arti saling mempercayai antarmanusia, tetapi juga kepercayaan atau keyakinan terhadap kekuatan superalamiah. Hal ini tidak bisa dilepaskan dari keyakinan, bahwa kekuatan superalamiah adalah bagian dari sistem sosiokultural pada desa Bondalem. Makhluk superalamiah ini tidak hanya ada, tetapi yang tidak kalah pentingnya adalah ada dengan kepemilikan kekuasaan yang bersifat super. Makhluk superalamiah bisa melakukan apa saja, sebab dia tidak terikat oleh waktu dan ruang. Keyakinan terhadap makhluk superalamiah yang bersifat superkuasa, lebih kuat dorongan untuk memaksa warga Bondalem dalam rangka berpartisipasi pada berbagai organisasi sosial seperti berpartisipasi dalam pemeliharaan daerah pantai dan laut.

\section{Implikasi penyertaan modal sosial terhadap kehidupan komunitas desa Bondalem sebagai Daerah \\ Perlindungan Laut.}

Implikasi nyata yang dapat dilihat dari penyertaan modal sosial terhadap kehidupan komunitas desa Bondalem sebagai Daerah Perlindungan laut adalah lestarinya terumbu karang di Desa Bondalem. Keadaan ini tidak bisa dilepaskan dari usaha dan kerja keras dari pihak-pihak terkait seperti masyarakat desa yang tergabung dalam kelompok Bahari Prawara Desa Bondalem, bekerja sama dengan yayasan Reef Check Indonesia, Pecalang Segara, Desa Pakraman, Kelompok Nelayan, Pihak Hotel yang ada di Desa Bondalem. Implikasi lainnya adalah meningkatnya hasil tangkapan nelayan serta meningkatnya tingkat kunjungan wisatawan ke Bondalem untuk melakukan diving dan snokling.

\section{PEMBAHASAN}

\section{Alasan maknawi/motif yang terkait dengan superstruktur ideologi, struktur sosial, dan infrastruktur material yang memberikan dorongan bagi Desa Bondalem membentuk Daerah Perlindungan Laut.}

Alasan ideologi dapat dilihat dari pengaplikasian ajaran Tri Hita Karana dalam tataran tingkah laku berupa pembentukkan Daerah Perlindungan Laut Berbasis Masyarakat. Daerah Perlindungan Laut Berbasis Masyarakat adalah (DPL-BM) adalah daerah pesisir dan laut yang dipilih dan ditetapkan untuk ditutup secara permanen dari kegiatan-kegiatan perikanan 
dan pengambilan sumber daya serta dikelola oleh masyarakat setempat. Kegiatan perikanan dan pengambilan merupakan hal terlarang di dalam kawasan DPL-BM. Demikian pula akses manusia di dalam kawasan DPL-BM diatur dan sedapat mungkin dibatasi. Pengaturan, pembatasan, dan larangan aktivitas tersebut ditetapkan oleh masyarakat dan pemerintah setempat dalam bentuk Peraturan Desa.

Struktur sosial dalam pengelolaan DPL-BM, memerlukan pendanaan dalam usaha memenuhi peralatan (infrastruktur material) dengan melakukan kiat-kiat tersendiri. Salah satu tantangan utama dari berbagai usaha pelestarian terumbu karang dimanapun ialah terkait pendanaan. Pengembangan pendanaan mandiri merupakan salah satu jalan keluarnya, berdasarkan konsep bahwa cara terbaik mendanai usaha-usaha ini ialah melalui pengembangan pendanaan yang bervariasi. Bondalem berusaha untuk mengimplementasikannya dengan mengembangkan portofolio self financing. Melalui program PNPM Mandiri Pariwisata, pemerintah desa Bondalem mengembangkan usaha pendanaan mandiri melalui pendirian kelompok Bahari Prawara, yang juga merupakan bagian dari unit pengelola DPL Bondalem

\section{Unsur-unsur pokok modal sosial yang} dikenal pada komunitas desa Bondalem yang bisa dikolaborasikan dalam kaitannya dengan modal-modal lainya (produce ekonomic capital, human capital, dan natural capital) guna mewujudkan pengembangan Daerah Perlindungan laut yang berkelanjutan termasuk di dalamnya hubungan mereka dengan lembagalembaga lain di luar desa mereka.
1. Tri Hita Karana

Sebagaimana

dikemukakan Atmadja (2008) anutan ideologi Tri Hita Karana atau Tri wacana pada masyarakat Bali tidak semata-mata karena terkait dengan agama Hindu, tetapi terkait pula dengan pengalaman orang Bali dalam kehidupan mereka. Secara empirik kehidupan mereka bergantung pada alam, manusia dan kekuatan adikodrati. Hal ini merupakan pola pikir yang sama dengan ideologi Tri Hita Karana. Berkenaan dengan kedatangan agama Hindu yang di dalamnya mencakup ideologi Tri Hita Karana mudah bisa diterima, karena sesuai dengan budaya lokal dalam bentuk kebergantungan manusia terhadap tiga hal guna memenuhi kesejahteraan hidupnya, yakni alam, manusia dan kekuatan adikodrati yang menentukan kehidupan manusia.

\section{Rasa percaya mempercayai (trust)}

Sebagaimana dijelaskan Fukuyama (1995), kepercayaan adalah harapan yang tumbuh di dalam masyarakat yang ditunjukkan oleh adanya perilaku jujur, teratur, dan kerjasama berdasarkan normanorma yang dianut bersama. Kepercayaan sosial merupakan penerapan terhadap pemahaman ini. Cox (1995) kemudian mencatat bahwa masyarakat yang memiliki tingkat kepercayaan tinggi, aturan sosial cenderung bersifat positif; hubunganhubungan bersifat kerjasama. Kepercayaan sosial pada dasarnya merupakan poroduk dari modal sosial yang baik. Adanya modal sosial yang baik ditandai oleh adanya lembaga-lembaga sosial yang kokoh; modal sosial melahirkan kehidupan sosial yang harmonis (Putnam, 1995). Kerusakan modal sosial akan menimbulkan anomie dan perilaku anti sosial.

Jurnal IImu Sosial dan Humaniora | 123 
Masalah-masalah sebelum Bondalem dijadikan Daerah Perlindungan Laut seperti penangkapan ikan dengan menggunakan bom (dinamit) ataupun dengan potas, dapat menyebabkan segala jenis ikan kecil akan musnah, penambangan terumbu karang, dapat diatasi dengan mengajak para nelayan untuk memiliki pengetahuan dan keterampilan memelihara terumbu karang dengan berbagai pelatihan.

\section{Nilai dan Norma Sosial}

$$
\text { Norma-norma terdiri dari }
$$

pemahaman-pemahaman, nilai-nilai, harapan-harapan dan tujuan-tujuan yang diyakini dan dijalankan bersama oleh sekelompok orang. Norma-norma dapat bersumber dari agama, panduan moral, maupun standar-standar sekuler seperti kode etik profesional. Norma-norma dibangun dan berkembang didasarkan sejarah kerjasama dimasa lalu dan diterapkan untuk mendukung iklim kerjasama (Putnam, 1993; Fukuyama, 1995). Norma-norma dapat merupakan pra kondisi maupun produk dari kepercayaan sosial.

Nilai-nilai yang dijadikan pedoman di Desa Bondalem dijiwai oleh Tri Hita Karana dan dalam bentuk awig-awig. Menurut Perda Bali No. 3 Tahun 2001 awig-awig adalah aturan yang dibuat oleh krama desa pakraman dan atau krama banjar pakraman yang dipakai sebagai pedoman dalam melaksanakan Tri Hita Karana sesuai dengan desa mawacara dan dharma agama di desa pakraman/banjar pakraman masingmasing.

\section{Resiprositas}

Resiprositas hubungan timbal balik antara individu dengan individu, individu dengan kelompok, kelompok dengan kelompok. Hal terlihat jelas dari berbagai kegiatan yang dilakukan oleh pihak-pihak yang berkepentingan terhadap DPL-BM di Bondalem. Pemerintah dalam hal ini berupaya untuk melestarikan terumbu karang sebagai upaya membantu mensejahterakan masyarakat. Pemerintah juga berharap masyarakat secara aktif ikut menjaga apa yang sudah dirintis oleh pemerintah bersama-sama tokoh masyarakat setempat.

\section{Tindakan Proaktif} Inisiatif atau tindakan proaktif dari dalam masyarakat Bondalem merupakan merupakan modal sosial yang sangat berharga, suatu program tidak akan mengalami keberhasilan apabila tidak dibarengi proaktif dari masyarakat setempat. Seperti yang dilakukan masyarakat Desa Bondalem dalam usaha menciptakan daerah Perlindungan Laut adalah Atas inisiatif masyarakat setempat, pada tanggal 13-14 November 2006, Tim Scientist Reef Check Indonesia melakukan program pelatihan penilaian sumberdaya partisipatif di Desa Bondalem kecamatan Tejakula, Buleleng. Seperti umumnya desa-desa di pesisir Bali, mata pencaharian utama masyarakat Bondalem adalah perikanan, rumput laut, dan pariwisata.

Reef Check mengakhiri pelatihan tersebut dengan membuat pemetaan kondisi karang di tanah menggunakan data yang mereka kumpulkan dalam Manta Tow. Melalui cara ini, masyarakat dapat melihat manfaat survey ini terhadap karang. Mereka melihat bahwa daerah yang paling rusak adalah yang paling banyak ikannya diambil, dan yang paling bagus kondisinya yang biasa digunakan turis.

Jurnal IImu Sosial dan Humaniora | 124 


\section{Dampak}

Pengelolaan sumberdaya kelautan berbasis masyarakat merupakan salah satu strategi pengelolaan yang dapat meningkatkan efisiensi dan keadilan dalam pemanfaatan dan pengelolaan sumberdaya alam. Selain itu strategi ini dapat membawa efek positif secara ekologi dan sosial. Pengelolaan sumberdaya alam khususnya sumberdaya kelautan berbasis komunitas lokal sangatlah tepat diterapkan, selain karena efeknya yang positif juga mengingat komunitas lokal memiliki keterikatan yang kuat dengan daerahnya sehingga pengelolaan yang dilakukan akan diusahakan demi kebaikan daerahnya dan tidak sebaliknya. Seiring trend di dunia yang sedang giat-giatnya mengupayakan penguatan institusi lokal dalam pengelolaan laut (pesisir).

Salah satu dampak positif adalah terjaganya kebersihan pantai, terumbu karang beserta ikan yang ada di dalamnya yang berimbas pada meningkatnya populasi ikan tangkapan, Termasuk di dalamnya ikan hias yang memiliki terbesar adalah damselfishes (Pomacentrus coelestis, Abudefduf septemfasciatus, Dascyllus trimaculatus, Chromis weberi, Pamacentrus lepidogenys, Chromis margaritifer) dan jenis wrasses (terutama Cirrhilabrus cyanopleura). serta bertambahnya jumlah kunjungan wisatawan yang berpengaruh terhadap tingkat hunia hotel (hotel Sangrila, Bali mandala)

\section{PENUTUP}

\section{Simpulan}

1. Alasan maknawi Bondalem yang terkait dengan superstruktur ideologi, struktur sosial, dan infrastruktur material yang memberikan dorongan bagi desa membentuk Daerah
Perlindungan laut adalah 1) adanya ideologi Tri Hita Karana yang menginspirasi setiap langkah dan tindakan untuk menyelamatkan terumbu karang yang di awal tahun 2000-an mengalami kerusakan akibat aktivitas pemanfaatannya yang berlebihan. Struktur sosial yang berperan terhadap pembentukan DPL di Bondalem adalah pihak pemerintah dalam hal ini diwakili oleh Dinas Kelautan dan Perikanan, LSM (Reef Check Indonesia), pihak pelaku pariwisata (pemilik hotel), unsur masyarakat Bondalem sendiri seperti desa dinas, desa pakraman, dan Pecalang Segara. Bentuk infrastruktur material yang diberikan oleh pihak pemerintah adalah bantuan alat selam, terumbu karang buatan, sedangkan pihak LSM (Reef Check Indonesia) memberikan bantuan berupa pelatihan cara transplantasi terumbu karang, pelatihan dasar menyelam bagi nelayan dan pihak segara prawara, serta pendampingan diawal pembentukan DPL. Pihak desa dinas berpartisipasi dengan membuat Perdes No. 5 Tahun 2006 tentang Perlindungan Pesisir dan Laut. Desa Pakraman dengan membuat awigawig yang melarang pembuangan sampah pelastik ke pantai guna mencegah kerusakan pantai dan terumbu karang. Pecalang segara berkontribusi dengan melakukan pengamanan di wilayah pantai berkoordinasi dengan pihak hotel dan nelayan kalau dijumpai adanya pelanggaran di DPL Bondalem.

2. Unsur-unsur modal sosial yang dikenal di Desa Bondalem adalah 1)Ideologi Tri Hita Karana, yang Jurnal IImu Sosial dan Humaniora | 125 
sudah diterapkan bukan lagi dalam tataran teks serta dapat dijadikan resep sosial dalam pembentukan DPL-BM di Desa Bondalem, 2) Trust yang tampak adalah berwujud keinginan dan atau tindakan untuk mengambil resiko dalam hubunganhubungan sosial, dengan suatu keyakinan, bahwa orang lain akan melakukan hal yang sama atau paling tidak mereka bertindak tidak merugikan dirinya sendiri, trust tersebut berimplikasi saling mempercayai antara pihak Desa Bondalem dengan pemerintah, LSM, dan pelaku pariwisata. 3) Nilai-nilai dan norma dituangkan dalam aturan awig-awig yang mengatur aspek parhyangan, pawongan dan palemahan. 4) Resiprositas, dalam konteks ini menyangkut resiprositas desa pakraman, desa dinas, pecalang segara serta resiprositas antar lembaga seperti pemerintah (Dinas Perikanan dan Kelautan dan pelaku ekonomi (pemilik hotel). 5) Tindakan proaktif, berupa keinginan yang kuat dari anggota kelompok tidak saja untuk berpartisipasi, namun juga mencari jalan yang lebih baik secara proaktif. 6) Kepercayaan terhadap kekuatan adikodrati yakni dewa-dewa dan roh leluhur yang ditaati karena dapat melakukan pengawasan dan mengenakan sanksi kepada siapapun tanpa terikat oleh waktu dan ruang.

3. Implikasi penyertaan modal sosial terhadap kehidupan komunitas DEsa Bondalem sebagai Daerah perlindungan laut adalah 1) lestarinya terumbu karang, 2)meningkatnya hasil tangkapan ikan, 3)Meningkatnya kunjungan wisatawan untuk melakukan diving dan snokling yang berimbas kenaikan pada tingkat hunian hotel.

\section{Saran}

1. Proses pendampingan terhadap masyarakat di Daerah perlindunga laut khususnya di Desa Bondalem harus tetap dilakukan sehingga kemajuan yang diperoleh tidak diganggu oleh pihak-pihak yang tidak bertanggung jawab.

2. Perdes dan awig-awig yang menjadi acuan dalam mengelola DPL di Bondalem hendaknya harus dijaga dan dilaksanakan dengan bersungguh-sungguh terutama di bagian sanksi agar diperberat sehingga memberikan efek jera bagi pelanggarnya.

\section{DAFTAR PUSTAKA}

Alwasilah, A.C. 2002. Pokok Kualitatif Dasar-dasar Merancang dan Melakukan Penelitian Kualitatif. Jakarta: Pustaka Jaya.

Atmadja, Nengah Bawa. 1993. Pelestarian Burung Kokokan (Bangau) di Desa Petulu, Gianyar, Bali. Singaraja: STKIP.

Atmadja, Nengah Bawa. 2008. Bali pada Era Globalisasi Pulau Seribu Pura Tidak Seindah Penampilannya. Yogyakarta: LKiS.

Badaruddin. 2005. "Modal Sosial (Social Capital) dan Pemberdayaan Komunitas Nelayan". Dalam M. Arif Nasutian, Badarrudin dan Subhihar ed. "Isu-isu Kelautan dari Keminskinan Hingga Bajak Laut. Yogyakarta: Pustaka Pelajar. Halaman 23-59. 
Dove, M. 1986. "The practical reason for weeds in Indonesia: peasant vs state views of Im-perata and Chromolaena, " Human Ecology 14(2): 163-90.

Dove, M.1990. The real and imagined role of culture in development: case studies from Indonesia. Honolulu: University of Hawaii Press.

Dove, M.1993. "Smallholder rubber and swidden agriculture in Borneo: a sustainable adaptation to the ecology and economy of the tropical rainforest, "Economic Botany 47(2): 136-47.

Ellen, R.F. 1985. Patterns of indigenous timber extraction from Moluccan rain forest fringes. Journal of Biogeography (12): 559-87.

Faisal, S. 2001. "Varian-varian Kontemporer Penelitian Sosial". Dalam Burhan Bungin ed., Metodologi Peneltian Kualitatif Aktualisasi Metodologis ke Arah Ragam Varian Kontemporer. Jakarta: PT RajaGrafindo Persada.

Fahmi, Erwin dan R. Yando Zakaria. 2010. "Good Governance dan Multi Stakeholders Processes". Wacana Jurnal IImu Sosial Transformatif. Edisi 20. Tahun VI 2010. Halaman: 95-114.

Fukuyama, F. 1995. Trust: The Social Virtues and The Creation of Prosperity, New York: the Free Press.

Fukuyama, F. 2005. Guncangan Besar Kodrat Manusia dan Tata Sosial Baru. (Masri Maris Penerjemah). Jakarta: PT Gramedia Pustaka Utama.

Gramsci, A. 2000. Sejarah dan Budaya. (Ira Puspitorini Penerjemah). Surabaya: Pustaka Promothea.

Gramsci, A. 2001. Cacatan-catatan Politik. (Gafna Riza Wahyudi Penerjemah). Surabaya: Pustka Promothea.
Hasbullah, J. 2006. Social Capital (Menuju Keunggulan Budaya Manusia Indonesia). Jakarta: MR-United Press.

Indonesia. Undang-Undang Nomor 32 Tahun 2004 Tentang Pemerintahan Daerah. Lembaran Negara Republik Indonesia Tahun 2004 Nomor 125.

Miles, M.B dan A.M. Hubermen. 1992. Analisis Data Kualitatif Buku Sumber tentang Metode-metode Baru. (Tjetjep Rohendi Rohidi Penerjemah). Jakarta: UI Press.

Pitana, Gd. 2008. "Pariwisata Bali dalam Jejaring Nasional dan Global". IBG Yudha Triguna ed. Kebudayaan dan Modal Budaya Bali dalam Teropong Lokal, Nasonal, Global. Denpasar: Fakultas Sastra Universitas Indonesia. Halaman 197-216.

Iskandar, Johan. 2001, Pemberdayaan Masyarakat Dalam Pengelolaan Hutan Mangrove, Makalah disampaikan dalam Pelatihan Peran Masyarakat Dalam Pengelolaan Lingkungan Hutan Mangrove, 29-30 Agustus, Lampung.

Putnam, Robert. 2000. Bowling Alone: The Collapse and Revival of American Community. New York: Simon and Schuster.

Shastri, Sunanda Y. dan Yajneshwar S. Shastri. 2005. "Ahimsa dan Kesatuan Segala Sesuatu Pandangan Hindu tentang Antikekerasan". Dalam Daniel L. Smith-Christopher (ed.). Lebih Tajam dari Pedang Refleksi Agamaagama tentang Paradoks Kekerasan. [Penerjemah: A. Widyamarta]. Yogyakarta: Penerbit Kanisius. Halaman: 107-136.

Subejo. 2010." Modal Sosial dalam Peranan Pengembangan Masyarakat Jurnal IImu Sosial dan Humaniora | 127 
Pedesaan". Jurnal IImu-IImu

Pertanian Vol. 4 No.1 Juli 2010.

Suharto, Edi. 2005. Membangun Masyarakat Memberdayakan Rakyat: Kajian Strategis Pembangunan Kesejahteraan Sosial dan Pekerjaan Sosial, Bandung: Refika Aditama.

Titib, I.Md. 2003. Teologi dan Simbolsimbol dalam Agama Hindu. Surabaya: Paramita.

Warren, C. 2008. "Capital Sosial di Bali Sinergi dan Tantangan". Dalam IBG Yudha Triguna ed. Kebudayaan dan Modal Budaya Bali dalam Teropong Lokal, Nasonal, Global. Denpasar: Fakultas Sastra Universitas Indonesia. Halaman 63-76.

Wiana, Kt. 1993. Bagaimana Umat Hindu Menghayati Tuhan. Denpasar: Manikgeni. 